\title{
Improvements of Prosthetic Limb Design: Cooling and Pressure Reduction in a Socket
}

Filip Tomanec, Sona Rusnakova, Milan Zaludek

Faculty of Technology, Thomas Bata University in Zlin. T.G.Masaryka 5555, 76001 Zlin, Czech Republic. E-mail: solvetech@solvetech.cz,rusnakova@utb.cz,zaludek@ft.utb.cz.

\begin{abstract}
Although important improvements of prosthetic sockets has been implemented another investigation has been done also by solving problems with inadequate stump heating and from that resulting excessive sweating of limb. This phenomenon is further associated with leg volume changes. Therefore for realization of this research the model of prosthetic limb was created with socket that further addresses these issues of artificial limb. Throw the application of holes and tightening bells the pressure to remaining stump decreased and at the same time the heating of limb is lower. These results indicate that the implementation of these design modification will improve the comfort and fit of prosthetic devices in future.
\end{abstract}

Keywords: Prosthesis, artificial limb, socket, design, stump.

\section{Acknowledgement}

This work and the project is realized with financial support of the internal grant of TBU in Zlín No. IGA/FT/2017/002 funded from the resources of specific university research.

\section{References}

[1] GHOLIZADEH, H., LEMAIRE, E.D., ESRAGHI, A. (2016). Sample paper in book. In: The evidence-base for elevated vacuum in lower limb prosthetics: Literature review and professional feedback, Clinical Biomechanics, pp. 108-116, ISSN 0268-0033. http://doi.org/10.1016/j.clinbiomech.2016.06.005.

[2] SANDERS, J. E., YOUNGBlOOD, R.T., HAFNER, B.J., CAGLE J.C., MCLEAN, J.B. REDD, C.B., DIETRICH, C.R., MARCIA A.C., ALLYN, K.J. (2017). Sample paper. In: Effects of socket size on metrics of socket fit in trans-tibial prosthesis users, Medical Engineering \& Physics, ISSN 1350-4533. http://doi.org/10.1016/j.medengphy.2017.03.003.

[3] WEBBER, C.M., DAVIS, B.L. (2015). Sample paper in book. In: Design of a novel prosthetic socket: Assessment of the thermal performance, Journal of Biomechanics, pp. 1294-1299, ISSN 0021-9290. http://doi.org/10.1016/j.jbiomech.2015.02.048.

[4] FOJTL, L., RUSNAKOVA, S., ZALUDEK, M., CAPKA, A., MANAS, L. (2017). Manufacturing and Mechanical Characterization of Bio-Based Laminates and Sandwich Structures", Materials Science Forum, Vol. 891, pp. 542546,2017

[5] SUBA, O., SYKOROVA, L., LUKOVICS, I. (2012). Stress analysis of injection - moulded cylindrical parts reinforced with short fibres. Manufacturing Technology. 2012, vol. 12, iss. 13, s. 251-254. ISSN 1213-2489.

[6] RUSNAKOVA, S., ZALUDEK, M., BAKOSOVA, D. (2012). Processing engineering of large composites structures using low-pressure vacuum infusion. Manufacturing Technology. 2012, vol. 12, iss. 12, s. 83-86. ISSN 12132489.

[7] HSU, M.J., NIELSEN, D.H., LIN-CHAN, S.J., SHURR, D. (2006). Sample paper in book. In: The Effects of Prosthetic Foot Design on Physiologic Measurements, Self-Selected Walking Velocity, and Physical Activity in People With Transtibial Amputation, Archives of Physical Medicine and Rehabilitation, pp. 123-129, ISSN 00039993. https://doi.org/10.1016/j.apmr.2005.07.310.

[8] PENG, J., FEY, N.P., KUIKEN, T.A., HARGROVE, L.J. (2016). Sample paper. In: Anticipatory kinematics and muscle activity preceding transitions from level-ground walking to stair ascent and descent, Journal of Biomechanics, pp. 528-536, ISSN 0021-9290. http://doi.org/10.1016/j.jbiomech.2015.12.041.

[9] HAN, Y., LIU, F., ZHAO, L., ZHE, J. (2016). Sample paper in book. In: An automatic and portable prosthetic cooling device with high cooling capacity based on phase change, Applied Thermal Engineering, ISSN 1359-4311. http://doi.org/10.1016/j.applthermaleng.2016.05.074.

[10] HUFF, E.A., LEDOUX, W.R, BERGE, J.S., KLUTE, G.K. (2008). Sample paper in book. In: Measuring residual limb skin temperatures at the skin-prosthesis interface,pp. 170-173

[11] DEANS, S.A.MCFADYEN, A.K. (2008). Sample paper in book. In: Physical activity and quality of life: a study of a lower limb amputee population, pp. 1753-1759

[12] DEANS, S., MCFADYEN, A., ROWE, P. (2008). Physical activity and quality of life: a study of a lower-limb amputee population, pp. 186-200 